\title{
Differences in the amino acid composition of muscles from pheasant and broiler chickens
}

\begin{abstract}
The present paper explores amino acid composition of breast and thigh muscles of common pheasant and compares it with that in broiler chickens. The experimental feeding of both pheasant and broiler chickens proceeded for a period of 42 days at the identical conditions employing the same diet and rearing technology. Muscles were analysed for the content of following amino acids: Asp, Thr, Ser, Glu, Pro, Gly, Ala, Val, Met, Ile, Leu, Tyr, Phe, His, Lys, and Arg. The results show that the levels of most amino acids in thigh and breast muscles of pheasants (related to dry matter content) were significantly higher $(\mathrm{P} \leq 0.01)$ than those in broiler chickens. In 42-day-old birds, the levels of individual amino acids in breast muscles (related to $100 \%$ of dry matter content) ranged from 8.02 to $127.32 \mathrm{~g} . \mathrm{kg}^{-1}$ in pheasant chickens and from 19.77 to $110.33 \mathrm{~g} . \mathrm{kg}^{-1}$ in

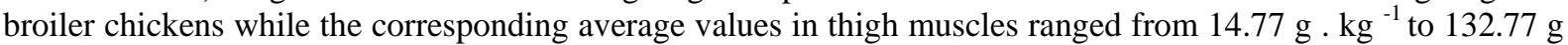
. $\mathrm{kg}^{-1}$ in pheasant chickens and from $14.02 \mathrm{~g} . \mathrm{kg}^{-1}$ to $93.53 \mathrm{~g} . \mathrm{kg}^{-1}$ in broiler chickens. One interesting finding is that in the case of broiler chickens the levels of most amino acids in breast muscles were significantly higher $(\mathrm{P} \leq 0.01)$ than those in thigh muscles. In the case of pheasant chickens, the difference between breast and thigh muscles was not confirmed which indicates that both muscles have high nutritive value. The results of amino acid composition of pheasant and broiler meat have proven a high nutritive value of pheasant meat in respect to human nutrition.
\end{abstract}

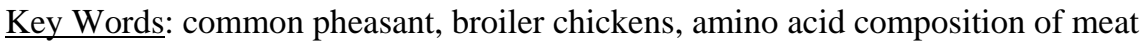

\section{Zusammenfassung}

Titel der Arbeit: Die Unterschiede in Aminosäuregehalten der Muskulatur von Fasanen- und Masthähnchen

Die Arbeit befasst sich mit der Untersuchung der Gehalte an Aminosäuren der Brust- und Schenkelmuskulatur des Edelfasans im Vergleich zum Masthähnchen. Eine Gruppe von 30 Fasanen und 30 Masthähnchen lag der Analyse zugrunde. Die Mast der Fasanen- und Broiler wurde über einen Zeitraum von 42 Tagen bei gleichen Ernährungs- und Haltungsbedingungen durchgeführt. Bei der Muskulatur wurde der Gehalt der folgenden Aminosäuren untersucht: Asp, Thr, Ser, Glu, Pro, Gly, Ala, Val, Met, Ile, Leu, Tyr, Phe, His, Lys und Arg. Die Ergebnisse weisen statistisch hochsignifikante $(P \leq 0,01)$ Werte für die meisten erfassten Aminosäuren in der Trockenmasse der Brust- und Schenkelmuskulatur von Fasanen im Vergleich mit Masthähnchen aus. In 100\% der Trockenmasse der Brustmuskulatur im Alter von 42 Tagen bewegten sich die einzelnen Aminosäuren von Fasanenhähnchen (Masthähnchen) im durchschnittlichen Wertebereich von 8,02 - 127,32 g . $\mathrm{kg}^{-1}$ (19,77 $\left.110,33 \mathrm{~g} \cdot \mathrm{kg}^{-1}\right)$, in der Schenkelmuskulatur im Bereich von 14,77 $\mathrm{g} \cdot \mathrm{kg}^{-1}$ bis $132,77 \mathrm{~g} \cdot \mathrm{kg}^{-1}\left(14,02 \mathrm{~g} \cdot \mathrm{kg}^{-1} \mathrm{bis}\right.$ 93,53 g . kg $\left.{ }^{-1}\right)$. Eine interessante Erkenntnis ist, dass es einen markanten Unterschied im Gehalt bei den meisten erfassten Aminosäuren zwischen Brust- und Schenkelmuskulatur der Masthähnchen gibt. Die Brustmuskulatur wies gegenüber der Schenkelmuskulatur signifikant höhere Gehalte $(P \leq 0,01)$ der meisten erfassten Aminosäuren auf. Bei den Fasanenhähnchen wurde kein Unterschied zwischen Brust- und Schenkelmuskulatur festgestellt, was einen hohen Nährwert sowohl der Brust- als auch Schenkelmuskulatur von Fasanen bestätigt. Die Unterschiede im Aminosäurenspektrum bei der Muskulatur von Fasanen- und Masthähnchen belegen den hohen Nährwert des Fasanenfleisches für die menschliche Ernährung.

Schlüsselwörter : Edelfasan, Masthähnchen, Aminosäurenspektrum der Muskulatur 


\section{Introduction}

Historically, game represented the major portion of meat consumed by man before the development of agriculture (STEINHAUSER, 2000). Recently, there have been some trends to revive and develop intensive pheasant farming. Pheasant farms and nurseries have to ensure that game receives adequate nutrition throughout the year, using supplemental or complete feeding mixtures. The dietetic assessment of pheasant meat was studied by a number of authors who focused particularly on basic analyses such as content of water, protein content, fat and ash, and the yield of carcass and individual parts (RICHTER, 1992; RICHTER et al., 1992). Exact data on the detailed chemical analysis of pheasant meat are not currently available in the scientific literature. Pheasant meat has a specific taste which results from different distribution of peptides, as compared with other kinds of meat (STRAKA and MALOTA, 2005). The quality of the carcass of farmed pheasant and broiler chickens can be assessed on the basis of a large number of criteria to evaluate sensory, morphological, histological, physical, chemical, health, hygienic and technological properties and features. UHEROVÁ et al. (1992) drew conclusion that game meat contains higher levels of essential amino acids, as compared with the traditional, currently produced kinds of meat. RICARD and PETITJEAN (1989) compared the composition of pheasant carcass with the carcass of broiler chickens of similar bodyweight. Changes in chemical composition of meat from pheasant and broiler chickens in the course of feeding was studied by VEČEREK et al. (2005). It follows from their results that chemical composition of pheasant meat significantly changes during growth. From a dietetic point of view, one important finding pointed out by the authors is that pheasant meat contains a high level of muscle proteins. QIONG et al. (2001) confirmed the effect of lysine and methionine in feed on the performance characteristics of young common pheasants during their growth, i.e. from hatching till the age of 8 weeks. The presence of Lys and Met in a diet was shown to affect the weight gain very significantly $(\mathrm{P} \leq 0.01)$. MELIN and LARBIER (1988) studied the effect of protein levels in a starter feeding mixture on the growth and plumage of pheasants. The amino acid composition of feather in diseased browneared pheasants (Crossoptilon mantchuricum) was studied by WANG et al. (1993). Variation in amino acid levels in the muscles of young broiler hybrids at prolonged feeding was studied by STRAKOVÁ et al. (2002).

The aim of the present study was to find out if there is difference in amino acid composition of breast and thigh muscles between fattening common pheasant (Phasianus colchicus) and broiler chickens aged of 24 days.

\section{Materials and Methods}

One hundred and ten chickens of common pheasant (Phasianus colchicus) and 110 broiler chickens (ROSS 308) were reared in aviaries on deep bedding in the accredited experimental enclosure of the Institute of Nutrition, Zoo-technology and Zoo-hygiene, at the University of Veterinary and Pharmaceutical Sciences in Brno, with controlled light, temperature and zoo-hygienic regimens observing the respective conditions of rearing technology. The sex of the birds was not determined. Pheasant and broiler chickens were fed ad libitum using a complete feeding mixture respecting nutrient and energetic demands for fattening of broiler chickens (Table 1). Microclimatic parameters of the experimental enclosure were as follows: the average daily air temperature ranged between 31 and $21^{\circ} \mathrm{C}$ depending on the age of chickens, the 
average daily humidity varied from 70 to $75 \%$, the light regimen during the whole period of feeding was 23 hours of light and 1 hour of dark. At the age of 42 days, 30 pheasant and 30 broiler chickens were randomly selected for chemical analyses of breast and thigh muscles. Pheasant and broiler chickens were slaughtered at the same age to the comparable experimental conditions were maintained. Dry matter content was determined by drying a homogenized sample of muscles at $105^{\circ} \mathrm{C}$ until constant weight. The amino acid composition of breast and thigh muscles was determined after acid hydrolysis in $6 \mathrm{~N} \mathrm{HCl}$ at $110^{\circ} \mathrm{C}$ for 24 hours, using the automatic amino acid analyser AAA 400 (INGOS a.s., Prague, Czech Republic) that measures the colour reaction between an amino acid and ninhydrin (the oxidizing agent). The following amino acids were evaluated: aspartic acid (Asp), threonine (Thr), serine (Ser), glutamic acid (Glu), proline (Pro), glycine (Gly), alanine (Ala), valine (Val), methionine (Met), isoleucine (Ile), leucine (Leu), tyrosine (Tyr), phenylalanine (Phe), histidine (His), lysine (Lys) and arginine (Arg). The resultant values of amino acids were re-calculated to $100 \%$ dry matter for the purpose of comparison. Mathematical and statistical processing of the results was based on the comparison of the resultant average values using the t-test implemented in the statistical programme UNISTAT. The following statistical characteristics are presented: arithmetic mean, standard deviation and the level of significance $\mathrm{P} \leq 0.01$.

Table 1

Nutrient composition of feeding mixtures administered to pheasant and broiler chickens (Nährstoffzusammensetzungen der Futtermischungen für die Mast von Fasanen- und Masthähnchen)

\begin{tabular}{|c|c|c|}
\hline $\begin{array}{ll}\text { Nutrient } \\
\left(\mathrm{g} . \mathrm{kg}^{-1}\right) \\
\end{array}$ & $\begin{array}{c}\text { BR } 1 \\
(1-20 \text { days of age }) \\
\end{array}$ & $\begin{array}{c}\text { BR } 2 \\
(21-42 \text { days of age }) \\
\end{array}$ \\
\hline Nitrogen substances & 230.79 & 210.60 \\
\hline Lysine & 13.87 & 12.05 \\
\hline Methionine & 5.23 & 4.97 \\
\hline Sulfur AA & 9.07 & 8.57 \\
\hline Threonine & 8.57 & 7.69 \\
\hline Tryptophan & 2.76 & 2.50 \\
\hline Arginine & 13.55 & 12.01 \\
\hline Fat & 65.94 & 72.78 \\
\hline Fibre & 32.99 & 32.16 \\
\hline $\mathrm{ME}\left(\mathrm{MJ} . \mathrm{kg}^{-1}\right)$ & 12.60 & 13.00 \\
\hline Ash & 65.17 & 61.50 \\
\hline $\mathrm{Ca}$ & 10.31 & 10.04 \\
\hline $\mathrm{P}$ & 7.10 & 6.51 \\
\hline Mg & 1.96 & 1.84 \\
\hline Linoleic acid & 32.57 & 36.10 \\
\hline $\mathrm{Na}$ & 1.82 & 1.81 \\
\hline $\mathrm{K}$ & 9.51 & 8.56 \\
\hline
\end{tabular}

\section{Results}

The amino acid composition of breast and thigh muscles from pheasant chickens aged 42 days was compared with that of broiler chickens of the same age. The overview of the results is provided in Table 2. The levels of individual amino acids in breast muscles from pheasant chickens aged 42 days (related to dry matter) ranged between 8.02 (Pro) and 127.32 (Glu) g . kg-1 and in broiler chickens they varied from 19.77 (Pro) to 110.33 (Glu) g . kg-1 (related to dry matter). It follows from the results (Table 2) that the levels of most amino acids in breast muscles from pheasant chickens were higher than those in broiler chickens. It was confirmed that 12 of a total of 16 amino 
acids analysed occurred in breast muscles from pheasants at a higher level as compared with broiler chickens. These differences were tested statistically highly significant ( $\mathrm{P} \leq 0.01)$. In the case of phenylalanine and lysine, the difference between the levels found in breast muscles of pheasants and broilers was tested statistically non-significant. However, the levels of threonine and proline in the breast muscles of broiler chickens were higher than those in pheasant chickens $(\mathrm{P} \leq 0.01)$.

The average levels of individual amino acids in thigh muscles (related to dry matter) ranged from 14.77 (Met) g . $\mathrm{kg}^{-1}$ to 132.77 (Glu) g . kg-1 in pheasant chickens and from 14.02 (Met) g . kg-1 to 93.53 (Glu) g . kg-1 in broiler chickens. In the case of thigh muscles (Table 2), 12 of a total of 16 amino acids analysed had higher levels $(\mathrm{P} \leq$ 0.01) in pheasant chickens in comparison with broilers, except for proline and histidine for which the average levels in pheasant chickens were significantly $(\mathrm{P} \leq 0.01)$ lower than those in broiler chickens. The levels of methionine and phenylalanine in thigh muscles of both species did not differ statistically.

The total sum of amino acids (related to dry matter) in broiler chickens was $786.86 \mathrm{~g}$. $\mathrm{kg}^{-1}$ in the case of breast muscles (essential AAs $-425.42 \mathrm{~g} . \mathrm{kg}^{-1}$ and non-essential

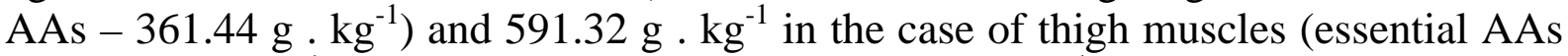
$-301.25 \mathrm{~g} \cdot \mathrm{kg}^{-1}$ and non-essential AAs $-291.07 \mathrm{~g} \cdot \mathrm{kg}^{-1}$ ). In the case of pheasant chickens, the total sum of amino acids (related to dry matter) was $844.94 \mathrm{~g} . \mathrm{kg}^{-1}$ in breast muscles (essential AAs $-450.36 \mathrm{~g} . \mathrm{kg}^{-1}$ and non-essential AAs - $394.58 \mathrm{~g}$.

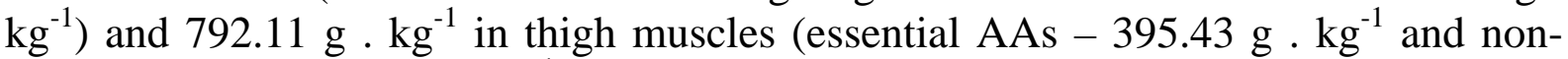
essential AAs - $396.68 \mathrm{~g} \cdot \mathrm{kg}^{-1}$ ).

Table 2

Amino acid composition of breast and thigh muscles from broiler $(\mathrm{n}=30)$ and pheasant $(\mathrm{n}=30)$ chickens aged 42 days (the results are related to $100 \%$ dry matter) (Das Aminosäurenspektrum der Brust- und Schenkelmuskulatur von Broilern $(n=30)$ und Fasanenhähnchen $(n=30)$ am 42. Masttag (Ergebnisse in 100\% der Trockenmasse))

\begin{tabular}{lcccc}
\hline \multirow{2}{*}{$\begin{array}{c}\text { Amino acid } \\
\left(\mathrm{g} . \mathrm{kg}^{-1}\right)\end{array}$} & \multicolumn{2}{c}{ Breast muscle } & \multicolumn{2}{c}{ Thigh muscle } \\
\cline { 2 - 5 } Asp & $78.98 \pm 2.810^{\mathrm{a}}$ & $84.83 \pm 5.037^{\mathrm{b}}$ & $59.59 \pm 3.600^{\mathrm{a}}$ & $79.85 \pm 6.818^{\mathrm{b}}$ \\
Thr & $36.55 \pm 2.020^{\mathrm{a}}$ & $31.31 \pm 8.572^{\mathrm{b}}$ & $27.78 \pm 2.540^{\mathrm{a}}$ & $40.73 \pm 21.301^{\mathrm{b}}$ \\
Ser & $30.58 \pm 1.790^{\mathrm{a}}$ & $37.60 \pm 11.131^{\mathrm{b}}$ & $25.79 \pm 1.490^{\mathrm{a}}$ & $40.86 \pm 11.398^{\mathrm{b}}$ \\
Glu & $110.33 \pm 6.180^{\mathrm{a}}$ & $127.32 \pm 6.659^{\mathrm{b}}$ & $93.53 \pm 5.860^{\mathrm{a}}$ & $132.77 \pm 10.718^{\mathrm{b}}$ \\
Pro & $19.77 \pm 2.960^{\mathrm{a}}$ & $8.02 \pm 5.084^{\mathrm{b}}$ & $19.39 \pm 2.350^{\mathrm{a}}$ & $15.77 \pm 8.484^{\mathrm{b}}$ \\
Gly & $37.45 \pm 2.450^{\mathrm{a}}$ & $40.15 \pm 3.024^{\mathrm{b}}$ & $34.39 \pm 3.030^{\mathrm{a}}$ & $47.45 \pm 6.399^{\mathrm{b}}$ \\
Ala & $49.13 \pm 1.890^{\mathrm{a}}$ & $53.49 \pm 4.261^{\mathrm{b}}$ & $37.90 \pm 2.260^{\mathrm{a}}$ & $53.92 \pm 5.948^{\mathrm{b}}$ \\
Val & $45.79 \pm 2.000^{\mathrm{a}}$ & $47.20 \pm 2.852^{\mathrm{b}}$ & $33.62 \pm 1.840^{\mathrm{a}}$ & $42.47 \pm 4.662^{\mathrm{b}}$ \\
Met & $20.77 \pm 1.730^{\mathrm{a}}$ & $23.53 \pm 2.832^{\mathrm{b}}$ & $14.02 \pm 1.710$ & $14.77 \pm 9.622$ \\
Ile & $42.28 \pm 1.460^{\mathrm{a}}$ & $44.65 \pm 3.806^{\mathrm{b}}$ & $30.86 \pm 2.880^{\mathrm{a}}$ & $41.58 \pm 5.268^{\mathrm{b}}$ \\
Leu & $68.79 \pm 2.070^{\mathrm{a}}$ & $79.61 \pm 6.239^{\mathrm{b}}$ & $51.23 \pm 4.600^{\mathrm{a}}$ & $73.58 \pm 7.263^{\mathrm{b}}$ \\
Tyr & $35.20 \pm 15.450^{\mathrm{a}}$ & $43.17 \pm 10.535^{\mathrm{b}}$ & $19.48 \pm 2.780^{\mathrm{a}}$ & $26.06 \pm 10.203^{\mathrm{b}}$ \\
Phe & $24.90 \pm 1.390$ & $24.59 \pm 13.126$ & $23.30 \pm 1.670$ & $21.23 \pm 12.333$ \\
His & $44.42 \pm 1.850^{\mathrm{a}}$ & $51.19 \pm 5.931^{\mathrm{b}}$ & $24.70 \pm 1.770^{\mathrm{a}}$ & $18.63 \pm 5.633^{\mathrm{b}}$ \\
Lys & $77.72 \pm 4.760$ & $77.77 \pm 15.681$ & $58.11 \pm 3.580^{\mathrm{a}}$ & $69.96 \pm 17.498^{\mathrm{b}}$ \\
Arg & $64.20 \pm 11.170^{\mathrm{a}}$ & $70.51 \pm 11.152^{\mathrm{b}}$ & $37.63 \pm 10.890^{\mathrm{a}}$ & $72.48 \pm 8.607^{\mathrm{b}}$ \\
\hline Data are means \pm standard deviation. & & & &
\end{tabular}

When analysing the differences between breast and thigh muscles within the species we have found that the average levels of most amino acids in breast muscles from broiler chickens are significantly higher than those in thigh muscles $(\mathrm{P} \leq 0.01)$ except for proline, glycine and phenylalanine for which the difference was not statistically 
significant. The phenomenon characterized by different levels of individual amino acids between thigh and breast muscles was not confirmed in pheasant, except for histidine whose average level in breast muscle (related to dry matter) was significantly $(\mathrm{P} \leq 0.01)$ higher than that in thigh muscle.

\section{Discussion}

Our results indicate that the levels of amino acids in breast and thigh muscles of common pheasant are higher than those in broiler chickens. The comparison of our results with literature data is rather difficult since available scientific literature has not yet addressed similar topics in detail, and we could only find partial studies on this topic. The study published by VEČEREK et al. (2005) is one of a very few studies available that deal with the chemical composition of breast and thigh muscles in common pheasant in the course of intensive feeding, pointing out to the high content of protein in pheasant meat. Our results comply with the findings reported by STRAKOVÁ et al. (2002) showing that the differences in amino acid composition are quantitative rather than qualitative and concern not only the kind of muscles (breast vs. thigh) but also species (broiler vs. pheasant). The amino acid composition of broiler meat was studied by INGR (1996) and SIMEONOVOVÁ (1999) who compared the levels of amino acids in breast and thigh muscles of broiler chickens.

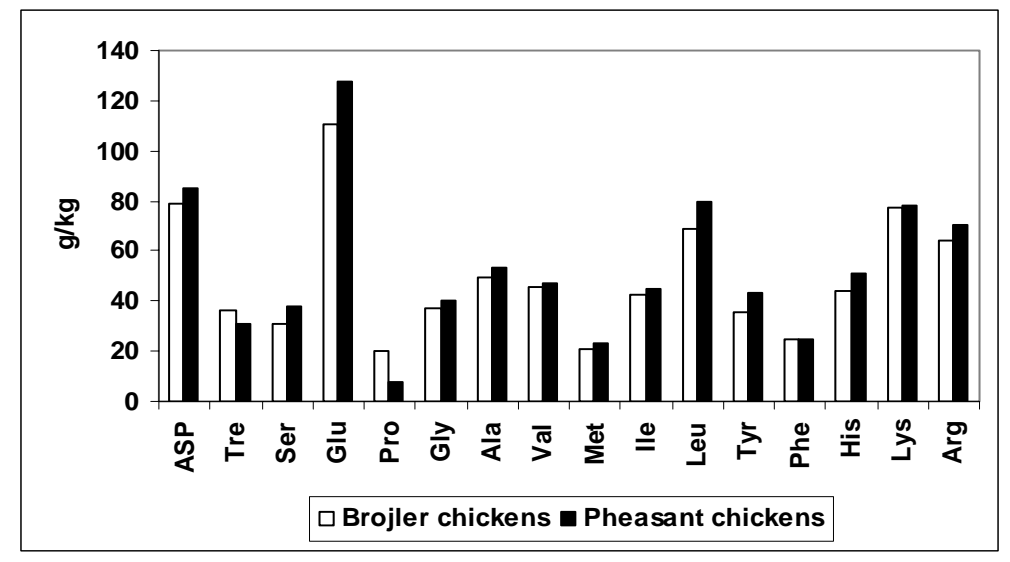

Fig. 1: The levels of amino acids in breast muscles of broilers and pheasants (Der Aminosäurespiegel in der Brustmuskulatur von Broilern und Fasanen)

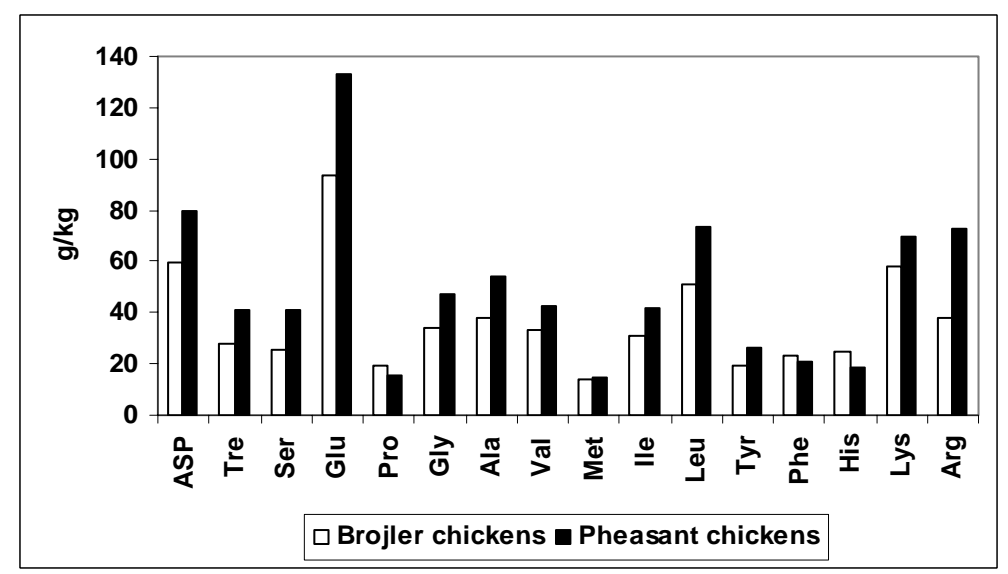

Fig. 2: The levels of amino acids in thigh muscles of broilers and pheasants (Der Aminosäurespiegel in der Schenkelmuskulatur von Broilern und Fasanen) 
Furthermore, our results are also in good agreement with the conclusions drawn by STRAKOVÁ et al. (2002) who found that the levels of individual amino acids as well as the total content of amino acids in breast muscles were significantly higher than those in thigh muscles. However, our results have shown that such conclusions only apply to broiler meat, not to pheasant meat. Furthermore, the results of this study have proven that pheasant meat has a high nutritive value that exceeds that of the meat from broiler chickens which is currently being promoted in human nutrition. The reason that pheasant meat has a high dietetic value is that it contains higher levels of essential amino acids in both breast and thigh muscles, as illustrated in Fig. 1 and 2. In this respect, the results of our work are in good agreement with those published by UHEROVÁ et al. (1992) and QIONG et al. (2001) who have reported that game is valuable particularly thanks to the high levels of lysine, methionine, and leucine. Lower $(\mathrm{P} \leq 0.01)$ levels of proline, the amino acid occurring typically in fibrous tissue, in breast and thigh muscles of pheasant (Table 2) also indicate in higher dietetic quality of pheasant meat.

Although our results cannot be compared directly with the findings made by other authors, the described biological experiment provided primary knowledge on the quality of breast and thigh muscles in feathered game. Problems addressed in this work may inspire breeders to shift to the area of the intensive breeding of feathered game aiming at the production of game meat to extend the range of high-quality meat with a high nutritive value on the market.

The knowledge of the amino acid composition of pheasant meat may also be used to design new feeding mixtures for farmed birds reared in aviaries and optimise the levels of amino acids in feeds according to the actual demand of common pheasant.

Acknowledgement

The work was supported from the Research Plan of the Ministry of Education, Youth, and Physical Training of the Czech Republic MSM 6215712402 "Veterinary aspects of food safety and quality“.

INGR, I.:

\section{References}

Meat Technology (in Czech). Mendel University of Agriculture and Forestry, Brno, 1996

QIONG, L.-Z; YING, Z.-K.; QUN, Z.-S.:

Influence of lysine and methionine levels in the diet on performance of young pheasants. J. Sichuan Agric. Univ., 19 (2001), 168 - 171

MELIN, J.M.; LARBIER, M.:

Effect of protein level in starter diet on growth and feathering performance of pheasant. Ann. Zootech., 37 (1988), 143 - 150

RICARD, F.H.; PETITJEAN, M.J.:

A comparison of the carcass compositions of game-type pheasants and broiler-chickens with similar body weights. Ann. Zootech., 38 (1989), 11 - 18

RICHTER, G.:

Carcass quality and nutrient content of meat: Special poultry and rabbits closely examined. Deutsche Geflügelwirtschaft und Schweinproduktion, 44 (1992), 605 - 608

RICHTER, G.; OCHRIMENKO, C.; GRUHN, K.:

Carcass composition and quality of quinea fowls, pheasants, pigeons, muscovy ducks and rabbits. Nahrung-Food, 36 (1992), 543 - 550 
SIMEONOVOVÁ, J.:

Technology of poultry, egg and minor animal products (in Czech). Mendel University of Agriculture and Forestry, Brno, 1999

STEINHAUSER, L.:

Meat production (in Czech). Last, Brno, 2000

STRAKA, I.; MALOTA, L.:

What about to have pheasant meat (in Czech). Náš chov, 65 (2005), 48 - 49

STRAKOVÁ, E.; JELÍNEK, P.; SUCHÝ, P.; ANTONÍNOVÁ, M.:

Spectrum of amino acids in muscles of hybrid broilers during prolonged feeding. Czech J. Anim. Sci., 47 (2002), $519-526$

UHEROVÁ, R.; BUCHTOVÁ, V.; TAKÁCSOVÁ, M.:

Nutritional factors in game. Fleischwirtschaft, 72 (1992), 1155 - 1156

VEČEREK, V.; SUCHÝ, P.; STRAKOVÁ, E.; VITULA, F.; MIKUNDOVÁ, M.:

Variation in the chemical composition of muscles in young pheasants during their growth. Arch. Tierz., Dummerstorf 48 (2005), 290 - 298

WANG, B.T.; YIN, G.R.; YANG, J.Y.:

Analyses on contents of some elements and amino acids of the feather in healthy and feather-picking brown pheasant. Acta Vet. Zootech. Sinica, 24 (1993), 93 - 96

Received: 2006-02-20

Accepted: 2006-05-31

Author's address

Doc. Ing. EVA STRAKOVÁ, Ph.D.*; Prof. MVDr. Ing. PAVEL SUCHÝ, CSc.;

Ing. FRANTIŠEK VITULA, Ph.D.; Prof. MVDr. VLADIMÍR VEČEREK, CSc.

University of Veterinary and Pharmaceutical Sciences Brno

Faculty of Veterinary Hygiene and Ecology

Palackého 1/3

61242 BRNO

CZECH REPUBLIC

*Corresponding Author

E-Mail: strakovae@vfu.cz 